\title{
Sciendo
}

\section{Automated Monsters of Vengeance: Comparing Goddesses in Ancient Greece and Hindu India}

\author{
CHARLES W. NUCKOLLS
}

Department of Anthropology, Brigham Young University, USA

charles_nuckolls@byu.edu

\begin{abstract}
Monsters that act "automatically," without thought or conscious awareness, constitute a category whose primary exemplar in American culture is the zombie. However, automaticity can be found in other realizations of the monstrous, including in ancient Greece and contemporary India. This paper compares the two. In Greece, the beings known as Eryines hunt and attack people who are guilty of crimes against members of their own kin group. One of the best examples is Orestes, whom the Erinyes pursue relentlessly because he killed his own mother, Clytemnestra. On the southeastern coast of India, among members of the Jalari fishing caste, there is a spirit called Sati Polalmma, who, like the Erinyes, attacks those who have broken oaths made to kin, especially oaths that concern sexual fidelity. The Erinyes and Sati Polamma are chthonic beings, associated with the earth, and are said to predate the patriarchal order of male deities. The paper explores automatic action as a characteristic of one category of the monstrous.
\end{abstract}

KEY WORDS: automaticity, chthonic monsters, Greece, South India 
But ancient Violence longs to breed, New Violence comes when its fatal hour comes, the demon comes to take her toll - no war, no fore, no prayer can hinder the midnight Fury stamped with parent Fury moving through the house (Aeschylus 2009: Agamemnon, 735-760).

\section{Introduction: Monsters on Automatic Pilot}

It is often held that to be a "monster," a being must terrorize other beings, leaving them no place to hide and at the mercy of the monster itself. The prototypic monster in American pubic culture - especially in the last decade or so - is the "zombie," a transformed human being now animated by only one imperative: To kill and consume. Zombies do not think, reason, or plan, nor do they possess any degree of conscious awareness. They are "set" on automatic. Perhaps automaticity deserves to be considered a characteristic of the monstrous. With this definition in mind, a comparison of Hindu South Asian and ancient Greek realizations of "the monster" becomes feasible. However, if one insists on incorporating "evil" into the definition, then the analysis must break down, for the simple reason that few beings in Hindu and Greek mythology are permanently or irredeemably evil. The demon king Ravana, for example, is the arch-villain who abducts Sita, wife of the god Rama (an incarnation of Vishnu), and takes her to his island stronghold of Lanka. With ten fearsome heads, Ravana is usually considered the embodiment of the wicked monster. But "evil" is not a term that can be applied, or rather, if Ravana is evil, it is only temporarily because, in the long run, he wishes to be good.

The story of Ravana goes like this: In the Bhagavata Purana, an ancient compendium of narratives focused on the god Krishna, Ravana and his brother, Kumbhakarna, were said to be reincarnations of Jaya and Vijaya, the gatekeepers at Vaikuntha, the heavenly abode of the god Vishnu. As gatekeepers they mistakenly refused entry to some holy monks - who, because of their powers and austerity, appeared as young children. For their insolence, the monks cursed Ravana and his brother to be expelled from Vaikuntha and born on Earth. They were given two choices: On the one hand, they could be born seven times as normal mortals and devotees of Vishnu. On the other hand, they could be reborn only three times as powerful and strong people, but as enemies of Vishnu. Eager to be back with the Lord sooner rather 
than later, they choose the latter option, even though it meant becoming wicked. The story only makes sense if Ravana and his brother are basically good, and worthy of final redemption.

So, it makes sense to begin with a more tractable definition of the monstrous, with a focus on the tendency of monstrous beings to seek out and torment their victims, and to do so automatically - that is, because they must. Where does this form of the monstrous come from? Kinship has a lot to do with it. In both contemporary South India and ancient Greece, "a kind of wild justice," to use Bacon's expression, wreaks vengeance on transgressors of vital kinship norms. Justice is "wild" because it is embodied in autochthonous spirits, automated and unstoppable, that live outside the political dimensions of society. These beings are associated with the earth, and with a time that antedates the birth of the gods and the order they uphold. They are female, and recognized, in dream and public drama, by their loose and disheveled hair, their bulging eyes, and their association with blood sacrifice. The norms they protect are understood as fundamental to the primary relationships between parent and child; husband and wife; and siblings. But wild justice, uncontained, threatens the social system no matter how righteous it is, and so, to keep justice under control, primal vengeance must be "domesticated." In Aeschylus this happens by subordinating vengeful monsters to the rule of law and the political order represented by the democratic city-state of Athens. Avenging monsters in South India are treated differently: Once propitiated, they become tokens of family solidarity and its continuity through time.

Here we consider two cultures, separated by thousands of years and thousands of miles: The Greek world of the fifth century B.C. and a Telugu-speaking fishing village on the southeastern coast of India. In the Athens of Aeschylus, vengeance as a kind of retributive justice undergoes partial replacement by the deliberative justice of the democratic polis. Autochthonous spirits associated with a society governed by kinship are subordinated to the Olympian gods and the emerging democratic nationalism of the city-state. In South India, by contrast, retributive justice assimilates itself over time, in each generation, to the ideal of family solidarity. Both can be viewed as processes of domestication, but whereas Greek vengeance becomes deliberative justice, South Indian vengeance is recycled within the household to become a genealogical symbol, an emblem of family continuity. 


\section{The Greek Erinyes: Monsters of Divine Retribution}

In ancient Greek, avenging monsters were known as Erinyes, "the angry ones," pitiless pursuers of those who violate filial duties. Aeschylus describes them as "accursed virgins, the ancient hags from some bygone age whose presence neither god nor man nor best can bear" (Aeschylus 2009, 68-70). In fact, the Erinyes were considered a force so instinctive and primeval that the Greeks said of them, "Even dogs have their Erinyes" (Monaghan 1997, 222). Sacrifices to them consisted only of "natural" products, not produced by farming, and in the sacrifice the offerings were totally consumed. "There is no need for knife and alter, for my feasting shall be upon your living flesh, you, the victim fattened ready for my sacrifice" (Aeschylus 2009: The Eumenides, 304-305). Not surprisingly, given Greek gender notions, they are also female, and act the way women are thought to act - viscerally, without reflection or deliberation, and with extreme and unremitting violence. Their power is especially potent because they are unmarried. They thus lack the patriarchal containment that is supposed to insure female energy is properly controlled and directed. But this makes them even more diligent in enforcing kinship norms; in fact, since the rule of men is associated with communal debate and decision-making in Greek drama, the authority of the Erinyes assumed the terrible capacity to act automatically, without deliberation, in defense of ancient kinship norms the Greeks defined as natural or prior to social organization.

The Jalari counterpart to the Erinyes is Sati Polamma, a monstrous goddess (ammavaru) who afflicts those who have sworn false oaths in matters of sexual fidelity. The Jalaris are a fishing caste people who live in village on the eastern coast of India. Each act of oath-breaking brings into existence its own Sati Polamma, and there are families in the fishing village that have more than one, because more than one transgression has taken place. Like the Erinyes, Sati Polamma responds automatically and violently to breaches in the kinship norms, especially where sexual misconduct is concerned. Let us say a married woman makes an oath that she has not committed adultery. If she lied, Sati Polamma will attack her, and no amount of rationalization or self-justification will suffice to assuage the monster that attacks her or members of her family.

In the Oresteia, it is true that the Erinyes, translated as "Furies," relentlessly pursue Orestes in order to avenge his murder of Clytemnestra, his mother. The Furies cannot be mollified or dissuaded by force of argument, since they represent primal beings that in Greek thought existed before the development of reason. They are creatures of the earth and the underworld. According to Plato, "those who have wasted their lives in wickedness are led by the Erinyes to Erebus and Chaos through Tartarus, where there is a place for the impious, and the ceaseless water-fetching of the Danaids, the thirst of Tantalus, the entrails of Tityus eternally 
devoured and regenerated, and the never-resting stone of Sisyphus, whose end of toil is always a new beginning." Their function is to punish violations of kinship norms without consideration of motivation or circumstance (Sidwell 1996). Violators are guilty of breaching the norms that govern social relationships.

Orestes is similarly afflicted, and defends himself in two ways. First, he calls attention to the motive behind his deed - he killed in order to avenge Clytemnestra's murder of his father, Agamemnon. Second, he names the god Apollo as the one who commanded him to take vengeance on his mother in the first place. Surely these were good enough reasons. After all, of the four main characters (Agamemnon, Clytemnestra, Orestes, Electra), Orestes is the only one who claims explicit divine sanction for transgressing kinship norms. That is why the Chorus can call the murder of his mother "blameless" (Aeschylus 2009: The Eumenides, 830); in fact, the word they use is not murder, but ate, the term that denotes divine punishment, and they say "Justice guided his hand" (Aeschylus 2009: The Eumenides, 948949). But the Furies are not susceptible to argument or evidence, and pursue Orestes until he finally seeks refuge in the temple of Athena and invokes her protection. There Orestes is put on trial before the Areopagus and Athena herself presides as judge. The two sides, Orestes and the Erinyes, present their cases, and the human jury votes. Orestes argues from reason and divine justification; his intent is pure, uncontaminated by the one emotion Greek drama invariably condemns most harshly - hubris. The Furies, on the other hand, are not at all concerned about these matters, but only with the unnatural death of a person at the hands of a relative (Aeschylus 2009: The Eumenides, 212, 421-427). They say, "For where is there such incentive to kill one's mother" (Aeschylus 2009: The Eumenides, 427)? The question comes down to choice between the emerging democratic ethos of modern Athens - with its stress on motivation and intention - and the older Homeric ethos of blood vengeance. The men of Athens are evenly split between exoneration and conviction. They are, as Helm points out, caught between the old and the new, "where the new has its allure but the old retains its claims" (Helm 2004, 50).

The remarkable shift in emphasis observed here involves not simply a substitution of a political institution for family vengeance in the administration of justice, important though that step is, but also allows for the consideration of motives in the judgment of guilt or innocence (Helm 2004, 51).

As ultimate arbiter, Athena, casts the deciding vote and frees Orestes, but not before compensating the Erinyes: Henceforth they will be known as the Eumenides, "the beneficent ones," and worshipped in a new shrine to be established in the city. In effect, the Furies are domesticated by making them subject to the will of men and the Olympian gods who 
represent the city's emerging status as a nationalist democracy. That is not to say they relinquish their power to avenge offenses against kinship, but their power to do so is implicitly circumscribed by the deliberative councils of the city (Vernant 2000).

\section{Sati Polamma: The Hindu Goddess of Broken Oaths}

Similar to the Erinyes is Sati Polamma, a Jalari goddess whose purpose is to afflict transgressors, especially those who have sworn false oaths in matters of sexual fidelity. Like the Erinyes, Sati Polamma is worshipped in no temple; she is thought to exist prior to, and independently of, mainstream gods and goddesses; and she is associated with the earth. Once she attacks, she attaches herself to the transgressor and his or her descendants forever, and must be propitiated once a year with blood sacrifice. That might seem like a case of inherited guilt, making Sati Polamma similar to the Erinyes, since Orestes and his family bear the taint of sins committed by earlier generations. But Sati Polamma, once installed in a family's pantheon, becomes a protecting deity, and afflicts those of other households who fail in their kinship obligations to the first family. She is, as it were, something of a spiritual firstresponder, known to attack automatically and violently the perpetrators of kinship misdeeds. Could this not be seen as kind of domestication of vengeance, not unlike what happens to the Erinyes when Athena accommodates them as protecting spirits of Athens?

Before considering this question, let us dwell for a moment on origins. In one sense, Sati Polamma has none, since no myth recounting her birth and kinship relations has ever been recorded. But here the matter quickly become complex. There is another goddess whose name is Sati, and she is not to be confused with her more widely known namesake, the goddess Sati who is the wife of the god Shiva. She is often conflated with Sati Polamma, the goddess of broken kinship oaths, and she is mother of all things, the female demiurge whose first act in the world she creates it to become hungry and lustful. She lays three eggs - an interesting fact in itself, given that she is not identified as an egg-laying being, like a chicken. And yet her elaborate epithets, recited every time she is propitiated, mention "wings" and the fact that she "crows" from the rooftops to announce her presence. In the Jalari account, her hunger drives her first to anger, and so she kicks one of the three eggs she has just produced. It breaks apart, and its pieces become the sky above and the ground below, and all the watery bits in between turn into the stars and planets. Then she pops the second egg into her mouth and eats it. The third egg, however, hatches on its own, and out of it emerge the trimurti ("three gods"), the famous Hindu triumvirate of Brahma, Shiva, and Vishnu. Sati sees her three sons, and is immediately overcome by sexual desire. First she propositions Brahma, 
who refuses her entreaties. She turns him into a stone. Then she approaches Shiva, and like his brother, he is turned into an inanimate object (a tree) when he refused his mother's sexual advances. Finally, there is Vishnu. He sees the fate that has befallen Brahma and Shiva, and so devises a ruse. He tells his mother he would be delighted to copulate with her, but only after she has taken a bath (after all, he says, she is still covered with pollution - maila - that accompanies childbirth). So she runs to the nearest body of water, to comply with his demand, but before she can actually reach it, the water is suddenly withdrawn. Vishnu has done this with a magic spell. She rushes back to him, in a state of ferocious anger, but once again her son stops her: "Mother," he says, "you must first give me all your magic formulae (mantras), and then I will lay with you." She complies, but as soon as Vishnu possesses her magic, he turns it on her and reduces her to a mound of ash. He then divides the ashes into four piles. From the first he constitutes the goddess (Sarasvati) who will be wife to Brahma. From the second he constructs Parvati, wife of Shiva. And from the third, he forms his own wife, the goddess Laksmi. Finally, with the fourth and last pile of ash, he refashions the mother, Sati. She exists again, but now merely as an ordinary woman, deprived of her power to do harm. She is "an old lady," who is meant to "sit by the hearth" and to accept whatever morsels of food her three new daughters-in-law decide to give her.

Is this Sati the same as the Sati Polamma who punishes oath-breakers? The answer is unclear. On the one hand, Jalaris distinguish between the creator goddess and the goddess who moves through the village "like a foul odor," punishing those who violate kinship norms. On the other hand, the two Satis are said to be the same, and both are described as derivative of the earth itself (bhumi). It is not unusual for Hindu deities to have multiple, even conflicting identities, so the Jalari account does not depart radically from tradition. In this case, however, the conflation serves a purpose: to ground - quite literally - the power of the goddesses in the earth itself, from which they, the goddesses, come and to which they ultimately return. One is reminded of the wife of Rama, yet another goddess named Sati, who ultimately finds her marital dignity impugned so severely that she causes the earth to swallow her up, and she is seen no more. It is therefore not surprising that when Jalaris make kinship oaths, promising they did not commit infractions, they stamp the earth three times. That is what "activates" Sati Polamma, and causes her to attack the oath-breaker. In short, since Sati the creator and Sati Polamma the punisher are chthonic deities, the order they represent is "pre-cultural," based in the origin of all things, and they stand independent of the institutions Jalaris believe are special province of men (and only men) to fashion and control.

As to the avian metaphors that abound in descriptions of Sati Polamma, and of all Jalari goddesses, this is harder to explain. On the one hand, there is the well-known Hindu myth of the hiranyagarba, "the golden womb," represented as an egg in the classical Puranas, or 
Hindu mythological compendia. In classical Hinduism, this egg is sometimes said to have given birth to Brahma, to whom otherwise goes the credit for creating the world. Elsewhere, the egg is described as rolling around and then breaking into halves, one half become the sky and the other becoming the earth. This obviously bears a similarity to the Jalari myth of the creator Sati and her three eggs. There is one critical difference, however. The Puranic myths do not speculate on the source of the egg, or of the creature that gives rise to it. The Jalari account, on the other hand, foregrounds this question, and identifies the genetrix as a kind of bird that lays eggs. It is, perhaps, a matter of emphasis. Jalari religion in centered on the worship of female deities, and male deities, to the extent they exist at all, are viewed as purely ancillary beings with no power of their own. The egg, therefore, grounds the Jalari account in a non-human or pre-human reality, purely feminine in orientation, that must be activated to produce the reality of today. Male-dominated institutions, the story implies, are secondary and derivative, while the true power of creation remains fundamentally female.

\section{The Chicken and the Egg}

Finally, in Jalari funerals, the chicken egg plays a special role. Every dead body is buried with an egg, usually placed on or near the shoulder. Men are buried face-up, and in a sitting position, with the egg on their right shoulder. Women are buried face-down, and prone, with the egg placed near the left shoulder. The egg, as we have seen, is a powerful symbol of creation and of re-creation. Its association with death, and with rebirth, should not surprise us. The chicken gives birth to the egg, say the Jalaris, and the egg gives birth to its own shell. Out of the shell, a kind of derivative mother, comes all of reality, including the principle male deities. The Jalaris say that in fact this makes the three gods the grandchildren, not the children, of the creator goddess. It is a somewhat tortured logic, but there is a sense to it. Because male children are often named after their maternal grandfathers, this means, in a sense, that the grandmother's husband has come back to life, making marital sexuality appropriate and predictable. When Sati propositions her three sons, therefore, she is not proposing incest with her own children, but rather she is proposing sex with her grandsons (who are incarnations of her own deceased husband). It is the cycle of departure and return, then, that the egg represents, and the association of egg-laying with a mother goddess who is chicken-like remains a potent source of analogies. 


\section{Marital Infidelity in a South Indian Fishing Village}

Now let us consider an example of Sati Polamma in action. A Jalari woman undertakes an adulterous affair, but denies it, and is then forced by her husband to swear an oath. She stamps the earth three times, and swears that she is innocent on pain of attack by the goddesses of broken promises, Sati Polamma. Later, the oath she has broken provokes the goddess Sati Polamma to wrath, and the woman (or a closely related family member) is attacked and made to suffer. She and her family consult a diviner, who reveals that the source of the attack is Sati Polamma, and that if the woman and her family wish to avoid more suffering, they must make a sacrifice to the goddess. The sacrifice is made and thereafter, every year (usually around the last week of December), the woman and her husband must sacrifice a chicken or a goat to the goddess. After they die, their children must continue the practice, and so must their grandchildren, if they are descendants in the male line.

Succession in the male line, however, is not the full story, even though it is the primary means of transferring the goddess between generations. It is also possible for a married woman to retain the Sati Polamma associated with her natal family. This is understood chiefly as a source of danger to the women of her husband's family, including her own daughters. The classic example, according to most Jalaris, is this: a young, pregnant woman happens to sit on the bed where her mother and father sleep. She then falls ill, and if remedial action is not taken, the pregnancy may result in a stillbirth.

It is not typical for the village as a whole to know when and where the sacrifices to Sati Polamma place, since husband and wife do their best to keep the ritual as secret as possible. After all, there is stigma associated with adultery and broken oaths, and most families do not want others to know such things have happened. Husband and wife generally make their ritual offerings to Sati Polamma at a location outside the village, either near the hill-top temple of Simhachalam or in downtown, in the large port city of Visakhapatnam, in close proximity to the temple of the goddess Ellamma. But as time goes by, and the first generation passes away, the sacrifice to Sati Polamma takes on more and more of the character of a household goddess ritual - an entirely public event, and one to which family and friends are invited. The sacrifice takes place on the beach, near the fishing village, and is announced by singing, dancing, and a fireworks display. No one refers to the misdeed that originally caused the "bad odor" to visit itself upon this family, although they do know about it. What, then, is the meaning of Sati Polamma at this point, and would it be fair to say it has changed? 


\section{The Domestication of Monsters}

Sati Polamma is not a household goddess (inti ammavaru) in the conventional sense because of her association with sexual transgression and oath-breaking. She is more the type of monster described earlier, the type that attacks viciously and automatically. But the logic of the household eventually wins out, even over Sati Polamma. Whether goddess, or monster, or both, she is partly domesticated - that is, assimilated to the household pantheon of spirits, becoming "like them" in her role as upholder of family solidarity and continuity through time. Domestication, in other words, means subordination to the most important principles in South Indian kinship. She is only partly domesticated, however, since her association with sexual guilt and oath-breaking make her unique, difficult to appease or placate, and always in need of blood sacrifice. Even the families that propitiate her, openly and publicly, do not feel entirely comfortable identifying her as a household spirit. She remains in a category by herself, not unlike the Erinyes, which do not relinquish their role as agents of vengeance even after Athena installs them as city goddesses in a cave at the base of the Acropolis.

The Erinyes undergo domestication in a different way, by being made subservient to the polis itself. The city represents the triumph of deliberative over retributive justice, of the younger Olympian gods over the sprits of blood vengeance. It is the strength and stability of the city, not the family, that Aeschylus celebrates. From then on, according to Aeschylus, justice must pass through the democratic process of the Areopagus, and ultimately, the verdict must reflect the triumph of the polis over everything (Monaghan 2002). The Oresteia's main purpose may not have been Athenian nationalism, but it certainly served that objective, because in the end, the Furies becomes subject to the city-state and must stand as its defenders. There is nothing similar in the Jalari case, because there is no political objective to be reached or political pride to be celebrated. It is the not the village that wins out in the end, but the household unit, to whose generational continuity everything can be sacrificed. The Greeks of Homer's time would have understood this better than Aeschylus and his counterparts, for whom the family was already being subsumed in the larger conditions of the city-state. So far, there has been no Jalari Aeschylus to suggest that the domestication of Sati Polamma could serve some higher end only made possible by the introduction of democratic decision-making.

For this reason, the Jalari system would seem like a reversion to a much more primeval ethos, but this should not surprise us. There has been no change, as there was in fifth century Athens, to a partial replacement of kinship-governed politics with the politics of democracy. The South Indian village remains a society largely governed by the norms of patrilineal succession and cross-cousin marriage. And this is true despite that fact that India is changing, and the village itself has gone from being an isolated coastal hamlet to a suburb of the 
expanding city of Visakhapatnam, one of the most important ports on the eastern coast. In the end, what we see is that the Furies are domesticated, but to different sociological ends in the case of Athens, to that of the democratic polis, and in the South Indian village, to that of important kinship processes.

Sati Polamma and the Erinyes become domesticated monsters, but no less monsters for that reason, since both pursue their victims with unremitting speed and force. As we have seen, both are almost entirely "automated," in that their punishing acts occur without thought and deliberation, with no possibility of switching them off until their victims suffer great afflictions. Even then, once the victim propitiates them, Sati Polamma and the Erinyes do not leave; they remain as permanent adjuncts to the associated family's or city's pantheons. In ancient Greece, this make the Erinyes similar to another automated force of punishment, the "miasma". Oedipus, in one account, is surrounded by miasma, but not pursued by the Erinyes for his unconscious commission of parricide and incest. In another account, however, miasma is not mentioned; instead Oedipus is attacked by the Erinyes, suggesting that, for all practical purposes, miasma and the Erinyes are closely related, if not identical. The point is that the Greeks had a number of different symbolic forms with which to imagine the operation of automatic justice. So, too, do the Jalaris of South India, since Sati Polamma is not alone but participates in a category of beings whose distinctive feature is that they cannot be fully placated. The monster, therefore, in both cultural contexts, is one whose depredations against the violators of kinship norms take place automatically and with the need for conscious deliberation.

\section{Final Thoughts: Pollution as an Attribute of the Monstrous}

There is, finally, another quality the Greeks and Jalaris share, and that is association between automatic justice - represented in the Erinyes and Sati Polamma - and "pollution" (maila in Telugu, miasma in Greek). Pollution of this sort, in both cultures, is connected with blood, and with the unclean and the defiled. Blood is the ultimate source of defilement, and it is not surprising that avenging spirits should be attracted to blood, and even to be born of blood. For consider: through her menstrual blood the daughter-in-law of Jalari family is said to convey her natal family's Sati Polamma into the household of her mother-in-law. A symbol of marital fecundity becomes a pathway for the conveyance of sexual sin, or for its residue the form of a broken marital oath. The two are too closely related for any Jalari to tell them apart, and this is what makes all women intrinsically dangerous. Orestes, on the other hand, is pursued because the blood of his mother is still on his hands. The Erinyes find him by 
smelling the blood and tracking it to its source. Once again, sin become the basis of affliction, but through the ritual process of sacrifice, the sin is turned into a source of power as the Erinyes undergo transformation into protective deities of the city of Athens.

\section{References Cited}

Aeschylus. 2009. Oresteia. Translated by Alan H. Sommerstein. New York: Loeb Classical Library.

Helm, James. 2004. "Aeschylus' Genealogy of Morals." Transactions of the American Philological Association 134: 23-54.

Monaghan, Patricia. 2002. The New Books of Goddesses and Heroines. Woodbury, Ml: Llewellyn Publications.

Sidwell, Keith. 1996. "Purification and Pollution in Aeschylus' Eumenides." The Classical Quarterly 46: 44-57.

Vernant, Jean Pierre. 2000. Myth and Tragedy and Ancient Greece. New York: Zone Books.

Charles W. Nuckolls is an anthropologist who works at the interface of cognitive science and psychoanalysis. His books include The Cultural Dialectics of Knowledge and Desire (University of Wisconsin Press), Siblings in South Asia (Guildford Publications), and Culture: $A$ Problem that Cannot be Solved (University of Wisconsin Press). Formerly he was Professor of Anthropology at Emory University and the University of Alabama. He is now Professor and former Chair of Anthropology at Brigham Young University in Provo, Utah.

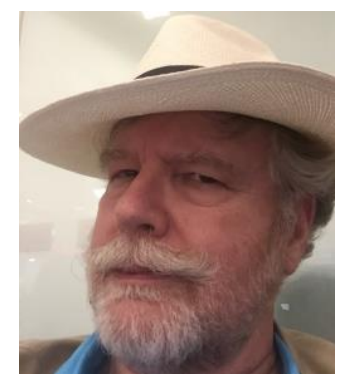

